\title{
Production and Maximum Sustainable Yield of fisheries activity in Hulu Sungai Utara Regency
}

\author{
Aroef Hukmanan Rais* and Tuah Nanda Merlia Wulandari \\ Balai Riset Perikanan Perairan Umum dan Penyuluhan Perikanan, Jln. Gub. HA Bastari, No.08 \\ Jakabaring, Palembang, Indonesia
}

\begin{abstract}
Production and fishing activities of inland waters in the Hulu Sungai Utara Regency (HSU) have a large contribution to fulfill the food needs for the local people in South Borneo. A total of $65 \%$ of the inland waters in the HSU Regency are floodplains. This research aimed to describe the production of capture fisheries products from 2010 to 2016, the catch per unit of effort (CPUE), the estimation of maximum sustainable (MSY), the biodiversity of fish species in the flood plain waters of Hulu Sungai Utara Regency (HSU). Research and field data collection was carried out throughout 2016, by collecting fishing gears and catch data from fishermen at Tampakang Village and Palbatu Village. The highest fish production was found in 2014, which reached a value of 2053 tons/year, and tended to decline in the following year. The highest catch per unit of effort per year was found to be in 2014 (151.65 tons/effort), and significantly dropped in 2016 (36.05 tons/effort). The Maximum Sustainable Yield (MSY) analysis obtained a value of 2103.13 tons/year with an effort value of 16.57 for standard fishing gear. The research identified 31 species of fish and the largest composition was baung (Mystusnemurus) and Nila (Tilapia nilotica).
\end{abstract}

\section{Introduction}

Hulu Sungai Utara Regency (HSU) is a region with a high potential of fishery production in South Kalimantan Province. This regency has 56,452 Ha of water areas or around $65 \%$ by total their territory, and around $95 \%$ or $54,129 \mathrm{Ha}$ is floodplain area [1]. The floodplain is an important area in fish ecology and holds the potential for fishery production. The people in HSU are depending on fishing activities for their economy and livelihoods in floodplain areas [2]. The total fisheries production in HSU regency reached 12,258.7 Tons in 2015 [3]. Because of the high potential, the district government of HSU regency has a vision on the development of floodplain for their people's welfare.

The fishing activity is the main fishery activity of people in HSU Regency's floodplain area. Besides fishing, floating cage aquaculture for a commercial commodity such as toman (Channamicropeltes) and baung fish (Mystusnemurus) is also common in the area. According to Rais et al (2018) [4], eleven kinds of fishing gears are utilized for fishing in the area. The Fishing activities are mostly traditional, where the activities themselves have been carried out for generations [5]. The daily fishing activities in the floodplain used many kinds of

\footnotetext{
* Corresponding author: aroefhr@gmail.com
} 
fishing gears, which caught both big-sized fish and small-sized fish alike, threatening the biodiversity [6]. To preserve the sustainability and continuity of the fishery resource in HSU Regency, the awareness of the status and the level of utilization of the fishing activity by the people must be raised. Limits of the utilization of resources is represented by the value of maximum sustainable yield (MSY), which estimates how many resources could be exploited sustainably in order to preserve it for the future [7]. The MSY value can be used to evaluate the fishing effort and serves as a basis to regulate the number of catch per unit effort (CPUE), in which the value is proportional to the stock biomass in the exploited phase [8].

This study aimed to analyze fisheries production from 2010 to 2016, to estimate the value of Catch per Unit Effort (CPUE) and Maximum Sustainable Yield (MSY), to estimate fish abundance, and to evaluate the current production status of fishery activity in Hulu Sungai Utara (HSU) Regency, South Kalimantan Province.

\section{Material and Methods}

\subsection{Method}

This research used primary and secondary data. Primary data was obtained from fishing production by fishermen as enumerators. Secondary data was obtained from fishing production data by Fisheries Agency of the HSU Regency and Center of Statistic Agency of HSU Regency. The fish production data were collected annually and categorized by various fishing gears, except the fishing gear which operated in the rivers. The secondary data collection was classified especially for the Danau Panggang subdistrict from 2010 - 2016. Primary data was collected on a small scale by the enumerators for ten months (March to December 2016). Sixteen fishermen were appointed as enumerators for both locations. The primary data collected was the production value from the effort for each fishing gear, estimated CPUE values, fish identification, and the catch composition. The sampling activity was performed in two villages, Palbatu and Tampakang villages (Figure 1). There were eleven kinds of fishing gears used: pancing pelampung (floating line), rawai baung (baung line), lukah baung (baung pot trap), jabak baung (baung trap), tampirai (trap), tamba seluang, hampang padang, selambau kasa, selambau sungai, lalangit (floating net) and rengge (gill net). Other collected data including fish diversity, total weight, and the number of fishing trips for a month. The fish caught were identified using Kottelat et al (1993) and FishBase $[9,10]$ as reference.

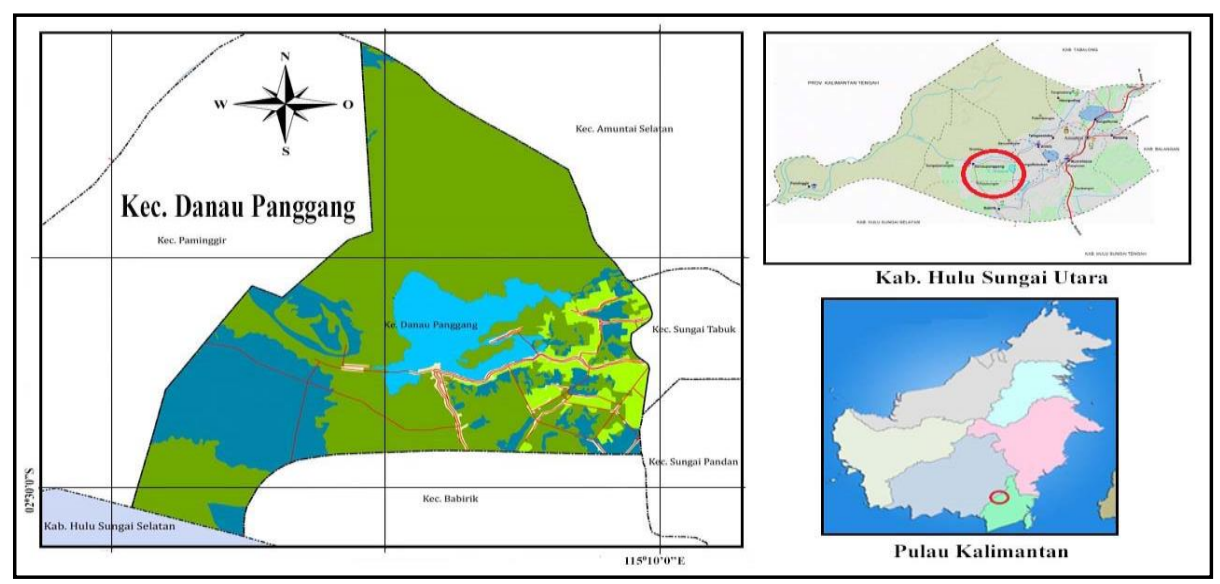

Fig. 1. Danau Panggang Subdistrict as sampling site location. 


\subsection{Data analysis}

The total production was obtained from fishing production data for each fishing gear from 2010 to 2016 . The fishing rate (1) for each year was calculated from the correlation between effort compared to fishing production [11]. standardized fishing production was needed to estimate the fishing rate for each fishing gear. The standardized fishing gear is the fishing gear with the highest productivity and has the highest fishing power index (FPI) (2) equal to one [12]. T-test analysis was used to analyze the correlation between CPUE to fishing production [13].

$$
\begin{gathered}
\text { Fishing rate }=\frac{C}{F} \\
\text { FPI }=\frac{\text { Fishing rate }}{\text { Maximum fishing rate }}
\end{gathered}
$$

with :

FPI = Fishing Power Index

$\mathrm{C} \quad=$ Production for each fishing gear

$\mathrm{F} \quad=$ Total amount of fishing gear was operationalized

Estimation of the Maximum Sustainable Yield (MSY) was carried out using methods by Sparre and Venema (1992) [14]. This method assumed the linearity between fishing effort $(F)$ with fishing production per effort $(C / F)$, in which the formulas are as follows:

$$
\begin{gathered}
a=\left[\frac{\sum y}{n}-\left(b \frac{\sum x}{n}\right)\right] \\
b=\frac{\sum x y-\frac{\left(\sum x\right)\left(\sum y\right)}{n}}{\sum x^{2}-\left(\frac{\left(\sum x\right)^{2}}{n}\right)} \\
r=\frac{\sum X i Y i-\frac{\left(\sum X i\right)\left(\sum Y i\right)}{n}}{\left[\left(\sum X i^{2}-\frac{\left(\sum X i\right)^{2}}{n}\right)\left(\sum Y i^{2}-\frac{\left(\sum Y i\right)^{2}}{n}\right)\right]^{1 / 2}} \\
y=a x+b x \\
\frac{C}{F}=a+b F \\
\text { MSY }=\left|\frac{a^{2}}{4 b}\right| \\
\text { F. MSY }=\frac{\alpha}{2 b}
\end{gathered}
$$

with :

$\mathrm{y} \quad=$ fishing production

$\mathrm{x} \quad=$ fishing effort or"effort", $F$, Standardized)

$\mathrm{r} \quad=$ Correlation coefficient (variable correlation between $\mathrm{x}$ and $\mathrm{y}$ )

MSY = (Maximum Sustainable Yield $)$

$\mathrm{F}_{\text {.MSY }}=$ Sustainable fishing effort 


\section{Results}

\subsection{Catch Production}

The total production for each fishing gear showed fluctuation in each year (Table 1). On each year the production of the fishing gears was not significantly different. The highest production was barrier traps for selambau sungai, while the highest production of line groups was pancing pelampung. The data showed an increase in the total fishing production value from 2010 to 2014, and decreased slightly from 2015 to 2016. Jaring sepat fishing gear have the smallest production, while selambau sungai have the highest productivity which reached 717.1 - 779.7 ton/year.

Table 1. Fish production for each fishing gears in Danau Panggang district floodplains

\begin{tabular}{lccccccc}
\hline \multirow{2}{*}{ Fishing Gear } & \multicolumn{7}{c}{ Total Production (Ton) } \\
\cline { 2 - 8 } & $\mathbf{2 0 1 0}$ & $\mathbf{2 0 1 1}$ & $\mathbf{2 0 1 2}$ & $\mathbf{2 0 1 3}$ & $\mathbf{2 0 1 4}$ & $\mathbf{2 0 1 5}$ & $\mathbf{2 0 1 6}$ \\
\hline Pancing Pelampung & 107.9 & 104.3 & 108.4 & 112.6 & 113.4 & 112.4 & 109.8 \\
Rawai Baung & 85.1 & 82.2 & 85.5 & 88.8 & 89.4 & 88.6 & 86.6 \\
Lukah Baung & 145.4 & 140.5 & 146.1 & 151.7 & 152.7 & 151.4 & 147.9 \\
Jabak Baung & 11.9 & 11.5 & 11.9 & 12.4 & 12.5 & 12.4 & 12.1 \\
Tampirai & 335.6 & 324.3 & 337.3 & 350.1 & 352.6 & 349.5 & 341.5 \\
Tamba Seluang & 33.8 & 32.6 & 33.9 & 35.2 & 35.5 & 35.2 & 34.4 \\
Hampang Padang & 240.2 & 232.1 & 241.4 & 250.6 & 252.4 & 250.1 & 244.5 \\
Selambau Kasa & 197.4 & 190.8 & 198.4 & 206 & 207.4 & 205.6 & 200.9 \\
Selambau Sungai & 742 & 717.1 & 745.8 & 774.3 & 779.7 & 772.8 & 755.2 \\
Lalangit & 28.3 & 27.3 & 28.4 & 29.5 & 29.7 & 29.4 & 28.8 \\
Jaring Sepat & 26.4 & 25.5 & 26.5 & 27.5 & 27.7 & 27.5 & 26.8 \\
\hline \multicolumn{1}{c}{ Total } & $\mathbf{1 , 9 5 3 . 8 0}$ & $\mathbf{1 , 8 8 8 . 1 0}$ & $\mathbf{1 , 9 6 3 . 8 0}$ & $\mathbf{2 , 0 3 8 . 7 0}$ & $\mathbf{2 , 0 5 3}$ & $\mathbf{2 , 0 3 4 . 9 0}$ & $\mathbf{1 , 9 8 8 . 6 0}$ \\
\hline
\end{tabular}

The fluctuation of fishing gear utilization from 2010 to 2016 is described in Table 2. Data collection showed fluctuation in fishing gear utilization for each year. Pancing pelampung has the highest total amount of utilization, while selambau sungai was the least used for fishing. Compared to Table 1, selambau sungai has the highest productivity compared to other fishing gears, contrary to its low amount of utilization.

Table 2. The total amount of fishing gears used in Danau Panggang flood plains for each year.

\begin{tabular}{lccccccc}
\hline \multirow{2}{*}{ Fishing Gear } & \multicolumn{7}{c}{ Amount (unit) } \\
\cline { 2 - 8 } & $\mathbf{2 0 1 0}$ & $\mathbf{2 0 1 1}$ & $\mathbf{2 0 1 2}$ & $\mathbf{2 0 1 3}$ & $\mathbf{2 0 1 4}$ & $\mathbf{2 0 1 5}$ & $\mathbf{2 0 1 6}$ \\
\hline Pancing Pelampung & 1,888 & 1,251 & 1,334 & 1,323 & 1,239 & 1,236 & 1,262 \\
Rawai Baung & 2,099 & 1,390 & 1,483 & 1,470 & 1,378 & 1,374 & 1,403 \\
Lukah Baung & 674 & 447 & 477 & 472 & 443 & 441 & 451 \\
Jabak Baung & 190 & 126 & 134 & 133 & 125 & 124 & 127 \\
Tampirai & 476 & 315 & 336 & 333 & 312 & 311 & 318 \\
Tamba Seluang & 12 & 8 & 8 & 8 & 8 & 8 & 8 \\
Hampang Padang & 55 & 36 & 39 & 38 & 36 & 36 & 36 \\
Selambau Kasa & 22 & 15 & 15 & 15 & 14 & 14 & 15 \\
Selambau Sungai & 8 & 5 & 6 & 5 & 5 & 5 & 5 \\
Lalangit & 118 & 78 & 83 & 83 & 77 & 77 & 79 \\
Jaring Sepat & 37 & 24 & 26 & 26 & 24 & 24 & 25 \\
\hline Total & $\mathbf{5 , 5 7 7}$ & $\mathbf{3 , 6 9 4}$ & $\mathbf{3 , 9 4 2}$ & $\mathbf{3 , 9 0 7}$ & $\mathbf{3 , 6 6 1}$ & $\mathbf{3 , 6 5 0}$ & $\mathbf{3 , 7 2 9}$ \\
\hline
\end{tabular}




\subsection{Catch per Unit Effort (CPUE)}

CPUE value was calculated by dividing the total catch production with a standardized fishing effort value used for one year. The value represented the fishing production for a fishing effort using a unit of standardized fishing gear. The total catch value compared to the fishing effort is shown in the CPUE graph (Figure 2). In Figure 2, it can be observed that the CPUE tended to experience an upward trend from 2010 to 2014, and has decreased significantly in 2016. The highest CPUE was recorded in 2014, which reached 151.7 tons/effort, and the lowest value in 2016 which only amounted to 36.05 tons /effort. Different values are shown from the production graph in 2011, and production tended to rise in the following year and then decreased in 2015 and 2016. The t-test was used to calculate the correlation of CPUE and catch production parameters. The relationship of both parameters in the t-test showed a correlation that was significant at the $95 \%$ confidence level $(\mathrm{P}<0.05)$.

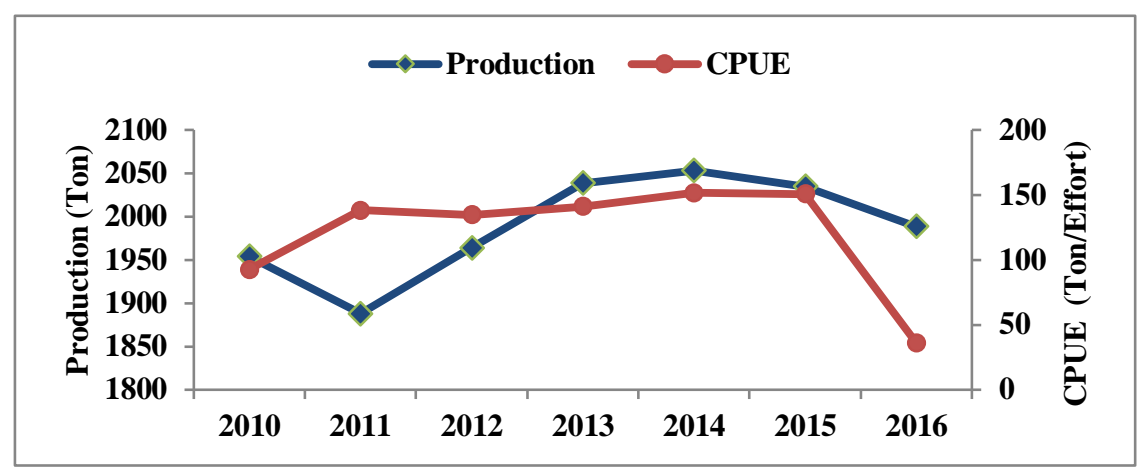

Fig. 2. Comparison between production and CPUE during 2010-2016.

\subsection{Maximum Sustainable Yield (MSY)}

The limitations of fish resources that can be utilized while still accounting for its sustainability were illustrated in the Maximum Sustainable Yield (MSY) graph (Figure 3). The magnitude of the value of MSY was strongly influenced by the amount of catch production compared to the standardized catching effort. The regression relationship of the number of standardized fishing gears used for fishing production was $y=253.82 \mathrm{x}-7.66 \mathrm{x} 2$, with $r=0.997$ (Figure 3). The regression was applied as the value of sustainable catch production to the number of standardized fishing gear/effort carried out to parabola graph with the peak value of MSY production $=2.103 .13$ tons, and standard catch effort (F.MSY) $=16.57$ standard fishing gear, where the fishing gear used as standard was selambau sungai.

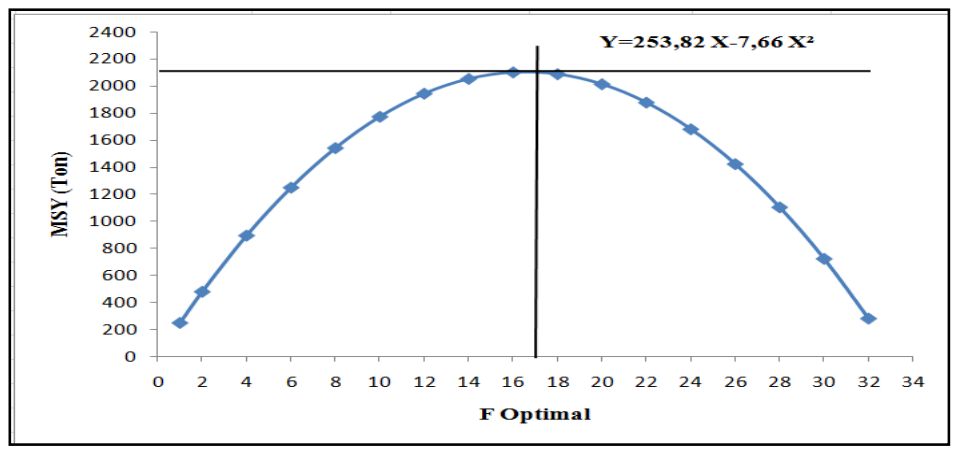

Fig. 3. Maximum Sustainable Yield graph in Danau Panggang District 


\subsection{Fish Catch Composition}

The fish catch composition was obtained from observations of catches using eleven fishing gear operated in the Danau Panggang floodplains. The fish identification obtained 31 species that were caught in this study (Table 3). The total catch showed that the Danau Panggang has a large amount of baung fish (Mystusnemurus) which made up to $17.9 \%$ of the total catch. A number of species with high economic value also caught, such as lais kuning (Kryptopterus schilbeides) $10.48 \%$, patin (Pangasius djambal) $10.31 \%$, and tilapia (Tilapia nilotica) $13.57 \%$. Other economically important fish were caught in fewer numbers such as haruan (Channastriata) 4.97\%, lais tabirin (Belodontichthys dinema) $0.09 \%$, and tapah (Wallago leeri) $0.17 \%$.

Table 3. The fish composition was caught in Danau Panggang flood plain.

\begin{tabular}{|c|c|c|c|c|}
\hline No & Local Name & Scientific Name & Total (kg) & Percentage $(\%)$ \\
\hline 1 & Baung & Mystus nemurus & $4,282.72$ & 17.93 \\
\hline 2 & Papuyu & Anabas tetudineus & 242 & 1.01 \\
\hline 3 & Bintuhukan & Thynnichthys thynnoides & 6 & 0.03 \\
\hline 4 & Birahmata & Amblyrhynchichthys truncatus & 14.4 & 0.06 \\
\hline 5 & Haruan & Chana striata & 1,188 & 4.97 \\
\hline 6 & Jelawat & Leptobarbushoeveni & 10 & 0.04 \\
\hline 7 & Kalabau & Osteochilus kalabau & $1,292.50$ & 5.41 \\
\hline 8 & Kerandang & Channa pleurophthalma & 87.3 & 0.37 \\
\hline 9 & Lais & Phalacronotus micronemus & $1,374.60$ & 5.76 \\
\hline 10 & Laiskaca & Kryptopterus minor & 314.8 & 1.32 \\
\hline 11 & Laiskuning & Kryptopterus schilbeides & $2,502.90$ & 10.48 \\
\hline 12 & Laistabirin & Belodontichthys dinema & 20.5 & 0.09 \\
\hline 13 & Laisputih & Kryptopterus kryptopterus & 5 & 0.02 \\
\hline 14 & Lampam & Barbonymus schwanenfeldii & 4.8 & 0.02 \\
\hline 15 & Lawang & Pseudolais micronemus & 668.5 & 2.8 \\
\hline 16 & Manangin & Thynnichthys polylepis & 4 & 0.02 \\
\hline 17 & Mangki & Rasboratri fasciata & 466.7 & 1.95 \\
\hline 18 & Nila & Tilapia nilotica & $3,241.80$ & 13.57 \\
\hline 19 & Patin & Pangasius djambal & $2,462.10$ & 10.31 \\
\hline 20 & Pentet & Clarias bratachus & 37.8 & 0.16 \\
\hline 21 & Patung & Pristolepis grootii & 91 & 0.38 \\
\hline 22 & Puyau & Osteochilus schlegelii & 741.6 & 3.1 \\
\hline 23 & Riu & Pangasius macronema & 28.5 & 0.12 \\
\hline 24 & Salap & Puntioplites falcifer & 719.2 & 3.01 \\
\hline 25 & Sanggang & Puntioplites bulu & 112.8 & 0.47 \\
\hline 26 & Sanggi & Mystus atrifasciatus & 61.5 & 0.26 \\
\hline 27 & Sepatmatahabang & Trichogaster lerii & 311 & 1.3 \\
\hline 28 & Sepat Siam & Trichogaster pectoralis & $2,969.53$ & 12.43 \\
\hline 29 & Tambakang & Helostoma temminckii & 576.2 & 2.41 \\
\hline
\end{tabular}




\begin{tabular}{lllll}
\hline 30 & Tapah & Wallago leeri & 41.6 & 0.17 \\
31 & Udang & Macrobrachium rosenbegii & 5 & 0.02 \\
\hline
\end{tabular}

\section{Discussion}

Fish production is related to ecological conditions in the floodplain area, which is strongly influenced by the fluctuations of the hydrology of the water. Many floodplain fish have biological pattern are nearly related to the habitat waters condition [15]. Whereas for fishing activity, the fishery production is largely determined by the presence and the fishing gear utilized by the community. Generally, fishing gears in the floodplain are passive fishing gear that worked as a trap, placed in narrow and shallow waters and specifically made for catching local migratory species [16]. Fishing gear in the Danau Panggang floodplain is divided into four groups, hook and lines, traps, barrier traps, and nets [4]. Fishing gears that are categorized as hook and line (pancing pelampung and rawai baung), and nets (lalangit and jarring sepat) have fewer of production because of the relatively high selectivity and target species. Lines fishing gears are more selective for haruan (Channa striata), and selective rawai baung for baung (Mystus nemurus). From the nets group, the lalangit and the jaring sepat are more selective for sepat siam (Trichogaster pectoralis), tampakang (Helostoma temminckii), and papuyu (Anabas testudineus). The barrier trap fishing gear has very high productivity because it blocks the natural flow of water and the migration movement of fish from swamps to rivers and vice versa. This type of fishing gear will catch various types and sizes of fish, hence increased selectivity is an alternative method to avoid catching juvenile population [17]. The production from 2010 to 2014 has increased due to the increase in the number of fishing gear, but from 2015 to 2016 the production declined. The declination could be caused by excessive exploitation, where the number of fish stocks remained or decreased but the number of fishing gear or the trend of effort increased. The decreasing proportion of catch compared to the number of effort indicates the occurrence of overfishing [18].

Selambau kasa and selambau sungai have high productivity but were not widely used due to the high cost of production. Besides blocking the water flow and the migration path of fish, the gear itself is considered very dangerous because it can break the biological pattern of the fish. Most of the fish in the floodplain would move up to the shallow area (when flooded) to the spawning area and return to the river [16]. The high number of fish that were caught without size selectivity would cause ecological pressure and would eventually change the size of fish caught, the body size for gonadal maturation, and the overall sustainability of fish resources [19]. The fishing gear on the lines group has good selectivity because it has a specific target species, the fishermen would use different bait for catching different targeted fish species [20].

CPUE values illustrated the catch effort capabilities using standardized fishing gear in a certain period of time. The CPUE graph (Fig. 3) showed a climbing trend in 2011 with declining production in the next year indicating poor catch results. It has caused fishermen to be in need of higher effort to catch fish compared to the other years. Fishing activities can be done by adjusting the type of fishing gear to the environmental topography, target fish species, and the number of fishing gear units [21]. Besides being closely correlated with the amount of catch obtained in a certain period of time, it was also influenced by several factors including rainfall. Rainfall affected the fluctuations and flow of water in the floodplain, thus became a factor that determined the distribution and migration of fish [22]. The statistical relationship through t-test showed a strong correlation between the production value and CPUE as a function of fishing effort. The conditions between the two parameters are strongly related, although there are environmental conditions that cannot be resolved by increased fishing efforts such as prolonged floods, low tide, or dry season which caused some fishing 
gear to be unable to reach their maximum catch capacity. To meet the market demand for fish, the fishermen raise their effort by changing the fishing gear which is more suitable to the field condition for maximum production [4].

With the high intensity of fishing in the Danau Panggang area, the assumption of overfishing value was reasonable. The maximum sustainable yield (MSY) analysis has obtained maximum sustainable production value in Danau Panggang of 2,103.13 tons, and standard fishing effort (F.MSY) has 16.57 standard fishing gear. Fish production in the Danau Panggang was peaked at 2,053 tons/year in 2014, indicating that fish production had almost reached the maximum limit of fish resources that could be sustainably utilized. Generally, MSY models describe that the lower catch value compared to the value of surplus production indicates that the fishing activities are still sustainable; whereas the higher catch value compared to the surplus production model would signify that there is a decline in the fish population, which indicates unsustainable exploitation [23]. The sustainability describes how population structure is inseparable from the biological cycle conditions of fish resources themselves [18]. Biological pattern cycles are related to the success of natural food availability, breeding habitat, migration, and also the presence of prey and predators in an ecosystem [24]. The understanding and awareness of the stakeholders, who utilize and manage the resources, are that a profitable fishing production is best fitted to be less than $20 \%$ than MSY point [8]. To maintain the sustainability of fish resources, it is necessary to balance between fishing activities and the sustainability of the ecological cycle, which suppresses fishing activities during the breeding seasons or fish migration can help to restore stock and population structure.

A large number of baung fish were caught during the research. Baung fish has natural habitats in lakes and floodplains, and these fish have spawning cycles three times throughout the year and the peak season is in the rainy season [25]. Tilapia has a high abundance because it has good adaptability and has the ability to spawn throughout the year [26]. The biodiversity of fish in the floodplain waters of HSU Regency has a good species diversity, where fish that have migratory characteristics were still present in the area. This showed that the floodplain ecosystem in HSU Regency was still good and needed to be maintained. As long as the fish resources remain sustainable, it would be profitable to many communities. Even though the MSY value has been estimated and evaluated to avoid overfishing and control the CPUE, if the exploitation level exceeded the MSY it could lead to unwanted consequences such as the tragedy of the commons [27].

\section{Conclusion}

The fish resource management in Hulu Sungai Utara Regency needed to be given more attention to maintain the sustainability of the ecosystem. Regulation on fishing gear used in certain seasons is needed to maintain the ecological cycle of fish resources. Enforcement of the ban for destructive fishing practices and the development of local fish aquaculture can be an alternative in maintaining the amount of fish production without increasing the exploitation of fish resources.

\section{References}

1. Dinas Perikanan HSU. RPIJM Kawasan MinapolitanKab. Hulu Sungai Utara. Amuntai (2015).

2. O.T. Burgess, W.E. Pine, S.J. Walsh. Importance Of Floodplain Connectivity To Fish Populations In The Apalachicola River, Florida. River Research and Applications 29(6), 718-733 (2012). 
3. Badan Pusat Statistik Kabupaten Hulu Sungai Utara. Produksi dan nilai produksi ikan darat dirinci tiap Kecamatan Tahun 2014. https://hulusungaiutarakab.bps.go.id/subject/56/perikanan.html. (2014).

4. A.H. Rais, T.N.M. Wulandari, D. Emmy. Aktivitas Penangkapan dan Produksi Ikan di Hulu Sungai Utara Kalimantan Selatan. Jurnal Penelitian Perikanan Indonesia 24 (4), 227-238 (2018).

5. T.D. Beard, A. Robert, J.C. Steven, B.M. Peter, D.S. Sena, Devin. Ecosystem approach to inland fisheries: research needs and implementation strategies. Biology Letter 7 (46), $481-483(2011)$.

6. B. Chan, P.B. Ngor, Nam So, L. Sovan. Spatial and temporal changes in fish yields and fish communities in the largest tropical floodplain lake in Asia. Journal of Limnology 53, 485-493 (2017).

7. R. Froese, H. Winker, G. Coro, N. Demirel, A.C. Tsikliras, D. Dimarchopoulou, G. Scarcella, W.N. Probst, M. Dureuil, D. Pauly. A New Approach for Estimating Stock Status From Length Frequency Data. ICES Journal of Marine Science 75(6), 2004-2015 (2018).

8. V. Christensen. MEY = MSY. Fish and Fisheries 11,105-110 (2010).

9. M. Kottelat, A.J. Whitten, S.N. Kartikasari, S. Wirjoatmodjo. Freshwater Fishes of Western Indonesia and Sulawesi (Ikan air tawar Indonesia bagian Barat dan Sulawesi) (Periplus Edition-Proyek EMDI. Jakarta, 1993).

10. R. Froese, D. Pauly (eds). FishBase. World Wide Web Electronic Publication. www.fishbase.org, version (06/2018).(2018).

11. A. Nurhayati. Analisa Potensi Lestari PerikananTangkap di Kawasan Pangandaran. Jurnal Akuatika 4 (2), 195 - 209(2013).

12. Badrudin, B. Sumiono, S. Nurhakim. Analisa Data Catch \& Effort Untuk Pendugaan MSY (p. 1 - 14). Indonesia Marine and Climate Support (IMACS) Project.(2004).

13. S. Santoso. Aplikasi SPSS pada Statistik Multivariat(p. 47) (Elex Media Computindo, Jakarta, 2012).

14. P. Sparre, S.C. Venema. Introduction to tropical fish stock assessment. Manual. FAO Fish. Tech.Paper No. 365 (1) (FAO, Rome, 1992).

15. W.A. Hubert, K.L. Pope, J.M. Dettmers. Passive capture techniques. Fisheries techniques, $3^{\text {rd }}$ edition. American Fisheries Society. 223 - 265 (2012).

16. T.R. McClanahan, S.C. Mangi. Gear-Based Management of Tropical Artisanal Fishery Based on Species Selectivity and Capture Size. Fisheries Management and Ecology. The Wildlife Conservation Society 11, 51 - 60 (2004).

17. S. Nurdawati, Rupawan, S. Makmur, A.H. Rais. Aktivitas Perikanan Tangkap di Sungai Musi. Bunga Rampai Perikanan Perairan Sungai Musi Sumatera Selatan. Balai Riset Perikanan Perairan Umum, 209 (2010).

18. J. Kolding, P.A.M. Zwieten. Sustainable Fising of Inland Waters. Journal of Limnology 73(1), $132-148$ (2014).

19. J.D. Allan, R. Abell, Z. Hogan, C. Revenga, B.D. Taylor, R.L. Welcomme, K. Winemiller. Overfishing of Inland Waters. BioScience University of California Press. 55 (12), 1041 - 1051 (2005).

20. D. Grixti, D.C. Simon, P.L. Jones. The Effect Of Hook/Bait Size And Angling Technique On The Hooking Location And The Catch Of Recreationally Caught Black Bream Acanthopagrus butcheri. Fisheries Research 84, 338 - 344. (2007).

21. M. Bhattacharjee, M. Bhaskar. A Survey On Fishing Gears Used for Fishing in Sone Beel, The Largest Wetland In Assam, Northeast India. IJFAS 5 (4), 268 - 271 (2017). 
22. V.S. Kulkarni, P. Anandtheerth. Influence of Rainfall on the Seed Production of Indian Major Carps - a Case Study of T.B. Board Fish Farm, T.B. Dam, Hospet. International Journal of Innovative Research in Science, Engineering and Technology 4 (7) : 6210 (2015).

23. F.K. Siyal, Li Yuan., T. Gao. Q. Liu. Maximum Sustainable Yield Estimates of Silver Pomfret, Pampus argentus (Family: Strometidae) Fishery in Pakistan. Pakistan Journal Zoology 45 (2), 447 - 452 (2013).

24. S. Jennings, J.K. Pinnegar, V.C. Polunin, T.W. Boon. Weak Cross-Species Relationships Between Body Size And Trophic Level Belie Powerful Size-Based Trophic Structuring In FishCommunities. Journal of Animal Ecology 70, 934-944 (2001).

25. F.A. Adebiyi, S.S. Siraj, S.A. Hamrmin, C. Annie. Ovarian development of a river catfish Hemibagrus nemurus (Valenciennes, 1840) in captivity. Journal Exploration Zoology 315, 536 - 543 (2011).

26. E.A. Khallaf, G. Mansour, A. Mohammad. The Biology of Oreochromis niloticus in a Polluted Canal. Ecotoxicology 12, 405 - 416 (2003).

27. G. Hardin. The Tragedy of The Common. Science 162, 1243-1248 (1968). 